\title{
Foraging behaviour and diving pattern of Little Cormorant Phalacrocorax niger (Vieillot) (Pelecaniformes: Phalacrocoracidae) at Kallampara backwaters, Kerala, India
}

\author{
C. Zeenath ${ }^{1} \&$ V.J. Zacharias ${ }^{2}$ \\ ${ }^{1}$ Associate Professor, Wildlife Biology Division, P.G. Department of Zoology, Farook College, Kozhikode, Kerala 673632 , India \\ ${ }^{2}$ Professor, Division of Biology, Northern Virginia Community College, Manassas, VA 20109, USA. \\ Email: ${ }^{1}$ zeenathc@gmail.com
}

\begin{abstract}
The foraging behaviour and diving patterns of Little Cormorant Phalacrocorax niger were studied during August 2005 to March 2006 by direct observation of individuals foraging at Kallampara River $\left(11^{\circ} 09^{\prime} 25.5^{\prime \prime} \mathrm{N} \& 75^{\circ} 51^{\prime} 02.0^{\prime \prime} \mathrm{E}\right)$, near the Kadalundy Bird Sanctuary, Kozhikode District, Kerala, India. The individuals observed, foraged solitarily in shallow waters and displayed relatively short diving bouts composed of several dives $(25.3 \pm 5.75)$. The dive duration was positively related to surface resting time. Also, duration of dives decreased with increase in the number of dive cycles per bout. The mean diving efficiency was within the range reported for Phalacrocoracidae. Little Cormorants are opportunistic foragers utilizing the availability of prey to the maximum depending on tidal cycles. This study shows a specific relation between body mass, dive duration and diving efficiency.
\end{abstract}

Keywords: Diving bout, diving efficiency, diving pattern, foraging behaviour, Little Cormorant, Phalacrocorax niger, tidal influx.

Underwater activity of diving fowl is a fascinating field for researchers in ornithology. Although some dives are made during courtship or to escape from predators,

Date of publication (online): 26 December 2010

Date of publication (print): 26 December 2010

ISSN 0974-7907 (online) | 0974-7893 (print)

Editor: C. Srinivasulu

Manuscript details:

Ms \# 01819

Received 10 July 2007

Final received 01 December 2010

Finally accepted 07 December 2010

Citation: Zeenath, C. \& V.J. Zacharias (2010). Foraging behaviour and diving pattern of Little Cormorant Phalacrocorax niger (Vieillot) (Pelecaniformes: Phalacrocoracidae) at Kallampara backwaters, Kerala India. Journal of Threatened Taxa 2(13): 1382-1386.

Copyright: () C. Zeenath \& V.J. Zacharias 2010. Creative Commons Attribution 3.0 Unported License. JoTT allows unrestricted use of this article in any medium for non-profit purposes, reproduction and distribution by providing adequate credit to the authors and the source of publication.

Acknowledgements: The Authors are grateful to Dr. Jaffer Palo (Senior Scientist, Zoological Survey of India, Kozhikode) for his valuable suggestions. We are thankful to Director, Positional Astronomy Centre, New Alipore, Kolkota, for providing data source for tidal height.

\section{OPEN ACGESS | FREE DOWNLOAD (C) (i) (4)}

most are made to capture prey. Diving birds may be considered as central-place foragers (Orians \& Pearson 1979; Lessels \& Stephens 1983) which make repeated foraging excursions from the surface, to which they must return to breathe.

Cormorants are foot-propelled pursuit divers (Ashmole 1971). They typically forage by undertaking a series of dives from the water surface interspersed with brief recovery periods or surface pauses (Cooper 1986). The duration of dives is positively related to surface pauses or resting time (Casaux 2004). Cormorants and Shags belonging to the family Phalacrocoracidae are well adapted to dive in shallow waters (Wilson et al. 1992). The diving behaviour of cormorants is said to be influenced by environmental features (Frere et al. 2002) and it is reported that Red-legged Cormorants are able to forage by selecting the appropriate tidal condition to minimize foraging effort (Gandini et al. 2005).

The Little Cormorant Phalacrocorax niger is widely distributed throughout the Indian subcontinent (Ali 2002; Kumar et al. 2005) on inland waters, and also in brackish lagoons and tidal creeks. Understanding the foraging behaviour and diving pattern of this expert diver would be helpful in identifying its role in the wetland ecosystem, currently threatened by growing developmental activities. The aim of this study was to generate information on the foraging behaviour, diving pattern and the relationship between diving parameters and body mass of Little Cormorant.

\section{Study Area}

Observations were made at the Kallampara River $\left(11^{\circ} 09^{\prime} 25.5^{\prime \prime} \mathrm{N} \& 7^{\circ} 51^{\prime} 02.0^{\prime \prime} \mathrm{E}\right)$ near the Kadalundy Bird Sanctuary, Kozhikode District, Kerala, India. The river is a tributary of the Chaliyar River that joins the Arabian Sea near Beypore and it is subjected to regular tidal influx. The river attracts other wetland birds like the Indian Pond Heron Ardeola grayii, Grey Heron Ardea cinerea, Little Egret Egretta garzetta and Cattle Egret Bubulcus ibis. Scattered patches of mangroves such as Avicennia officinalis and Excoecaria agallocha grow along the riverside that foraging birds use as perching sites. 
Observations were held in a stretch of $5 \mathrm{~km}$ of Kallampara River.

\section{Methods}

The study was conducted from August 2005 to March 2006, mainly based on direct observational methods (Altman 1974). Data were collected from 1100 to $1600 \mathrm{hr}$, covering both low tide and high tide. We carried out focal observations on randomly selected foraging cormorants. Observations were made from convenient vantage points on the shore using a stopwatch and binoculars ( $8 \times 40)$. Data were recorded during high tide, the first quarter of receding tide (immediately after high tide), low tide and the first quarter of advancing tide (immediately after low tide). Tidal height at high tide varied between $1.28 \mathrm{~m}$ and $1.40 \mathrm{~m}$ and that of low tide was $0.40-0.46 \mathrm{~m}$. Depth profiles of the feeding locations were measured during different tidal conditions by physical method using a graduated pole.

Cormorants foraging solitarily were studied. The duration of a diving bout is taken as the time between submerging on the first dive of a series and surfacing after the last dive. A dive cycle consists of a single dive and a single surface pause. Diving efficiency is defined as the ratio between mean diving time and mean recovery period (Dewar 1924). Data collected from a series of dives and surface pauses (rests or recovery periods) from a number of individuals were pooled to give mean diving and surface resting periods, bout duration, dive cycles and dive/pause ratio. A mean value of each diving variable was determined for each diving bout, and means were pooled to calculate overall mean for an environmental condition. Values presented are means \pm S.D.

Two-way ANOVA was used to test significance of diving patterns during different tidal conditions. Duration of dives are correlated with pause duration and number of dive cycles per bout.

\section{Results}

Little Cormorant made foraging trips to inshore waters $<10 \mathrm{~m}$ deep. Average foraging depth was $3.83 \mathrm{~m} \pm 0.53$, $2.78 m \pm 0.39,1.34 m \pm 0.21$ and $1.08 m \pm 0.12$ at high tide, receding tide, low tide and advancing tide respectively.
In this study 20 diving bouts and 506 dive cycles were recorded (Table 1). Diving parameters showed variations at different tidal conditions. Under water time during each dive cycle varied between $66-75 \%$. Body weight of Little Cormorant was $444.67 \pm 38.59 \mathrm{~g}(\mathrm{n}=3)$.

Little Cormorants made foraging trips to inshore water $<10$ m deep near the bank within a small feeding range $(<1 \mathrm{~km})$. They followed a specific foraging pattern, which consists of perching near the inshore water prior to the beginning of the dive. After settling on the perch, the bird dropped into water and started diving. The first dive was followed by a short recovery period (surface pause) and then continued a series of alternative dives and surface pauses for a specific period (bout duration).

During different tidal conditions, surface pause duration increased with increasing dive duration (Fig. 1). It was found that duration of dive decreased with increase in the number of dive cycles per bout (Fig. 2). Duration of dives is positively correlated with pause duration $(R=$ $0.936, p<0.05)$, but negatively correlated to the number of dive cycles per bout $(R=-0.610, p<0.05)$.

Dive duration increased with height of the tide (diving depth). During high tide and receding tide it almost doubled (Fig. 4; $F_{12,486}=2.14, p<0.01$ ). In the Whisker

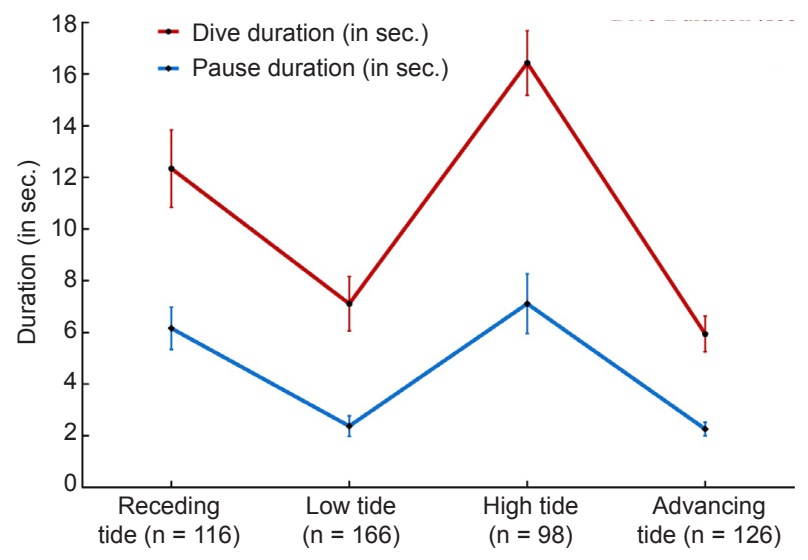

Figure 1. Pause duration (recovery time in seconds) as a function of dive duration performed by Little Cormorant at different tidal conditions.

Table 1. Mean diving parameters for the foraging Little Cormorant

\begin{tabular}{|c|c|c|c|c|c|c|c|c|}
\hline & Tidal condition & $\begin{array}{l}\text { No. of dive } \\
\text { cycles }\end{array}$ & $\begin{array}{l}\text { Bout } \\
\text { duration } \\
\text { (min) }\end{array}$ & $\begin{array}{l}\text { Dive \% } \\
\text { frequency } \\
\text { per hr. }\end{array}$ & $\begin{array}{c}\text { Dive } \\
\text { duration } \\
\text { (in sec.) }\end{array}$ & $\begin{array}{l}\text { Pause } \\
\text { duration } \\
\text { (in sec.) }\end{array}$ & $\begin{array}{l}\text { Dive / pause } \\
\text { ratio }\end{array}$ & $\begin{array}{l}\text { Time under } \\
\text { water }(\%)\end{array}$ \\
\hline 1 & $\begin{array}{l}\text { Receding tide } \\
(n=116)\end{array}$ & $23.20 \pm 1.79$ & $11.12 \pm 1.27$ & $3.49 \pm 0.22$ & $12.34 \pm 1.50$ & $6.16 \pm 0.82$ & $2.01 \pm 0.15$ & 66.70 \\
\hline 2 & Low tide $(n=166)$ & $33.20 \pm 3.35$ & $6.68 \pm 1.08$ & $8.36 \pm 0.72$ & $7.11 \pm 1.05$ & $2.37 \pm 0.40$ & $3.01 \pm 0.17$ & 75.03 \\
\hline 3 & High tide $(n=98)$ & $19.60 \pm 1.34$ & $8.23 \pm 1.52$ & $4.04 \pm 0.47$ & $16.43 \pm 1.25$ & $7.11 \pm 1.15$ & $2.33 \pm 0.21$ & 69.91 \\
\hline 4 & $\begin{array}{l}\text { Advancing tide } \\
(n=126)\end{array}$ & $25.20 \pm 5.97$ & $4.56 \pm 1.17$ & $9.27 \pm 0.70$ & $5.94 \pm 0.69$ & $2.26 \pm 0.26$ & $2.64 \pm 0.17$ & 72.46 \\
\hline
\end{tabular}




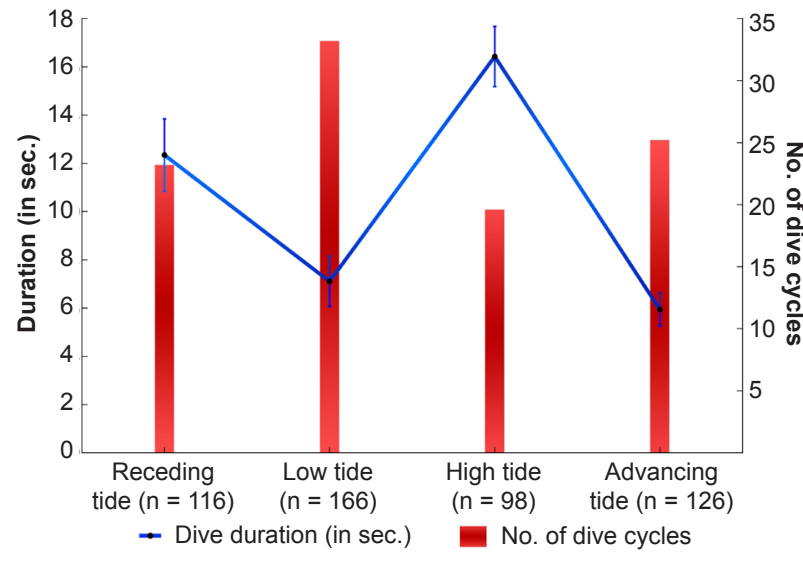

Figure 2. Relationship between number of dive cycles and dive duration.

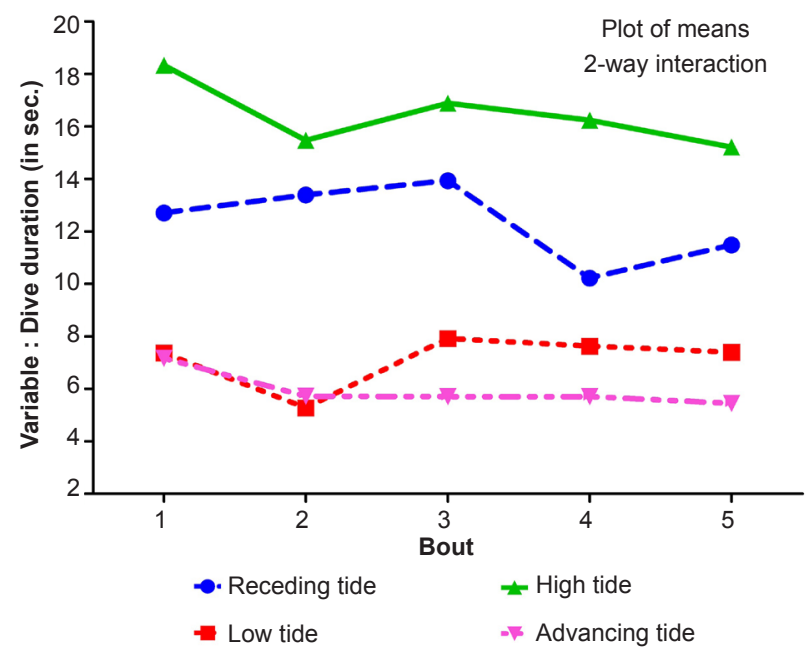

Figure 4. Relation between dive duration during different tidal cycles.

plot maximum diving efficiency is plotted against low tide (Fig. 5) and there is a negative correlation between tidal height (diving depth) and diving efficiency (Fig. $6 ; F_{12,486}=$ 2.90, $\mathrm{p}<0.001$ ).

The diving pattern during various tidal conditions shows significant differences $\left(F_{3,486}=67.61, p<0.05\right)$. The bouts $(n=20)$ during different tidal conditions in terms of dive duration, pause duration, dive cycles, dive $\%$ frequency per hour and dive/pause ratio are also very much significant $\left(F_{12,486}=2.90, p<0.001\right)$. Diving depth during different tidal conditions greatly influence the diving parameters. When the bouts are considered independently they are not significant $(p>0.05)$.

\section{Discussion}

A positive relation between dive duration and subsequent recovery time was observed in Little Cormorant as in other cormorant species (Cooper 1986; Croxall et al. 1991; Casaux 2004), but negatively correlated to

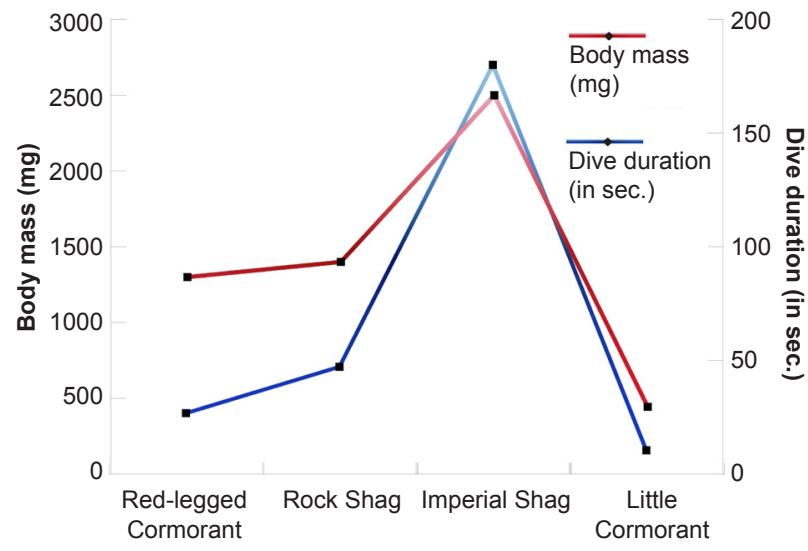

Figure 3. Relationship between dive duration and body mass of cormorants.

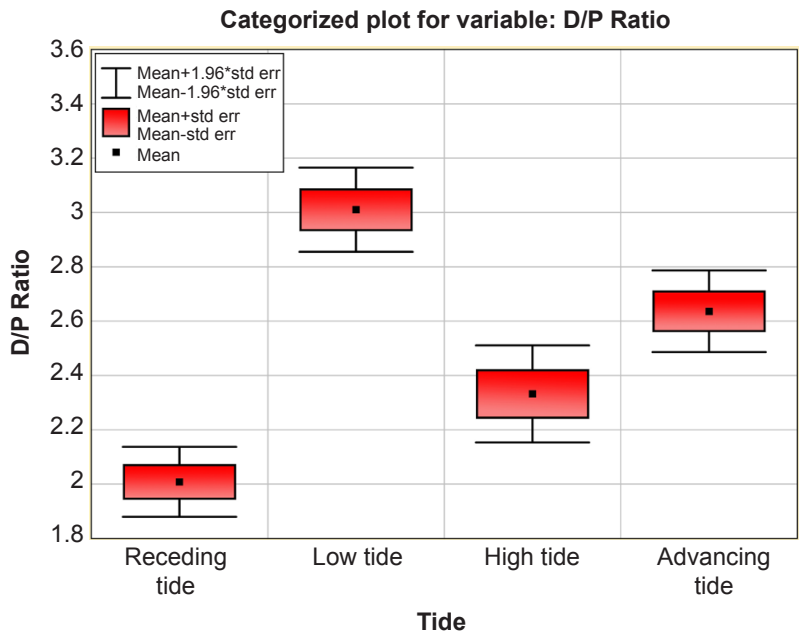

Figure 5. Box Whisker plot of dive/pause ratio at different tidal cycles.

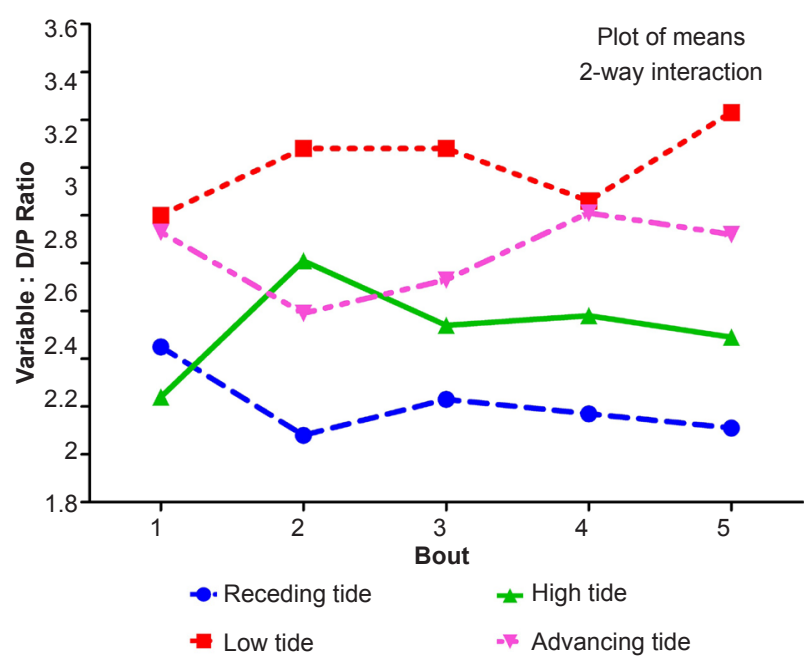

Figure 6. The relation between dive/pause ratio during different tidal cycles. 
the number of dive cycles per bout as in Antarctic Shag Phalacrocorax bransfieldensis (Casaux 2004).

When we consider the mean values for all the tidal conditions (Table 2$)$, it is clear that dives $(10.46 \pm 4.86 \mathrm{sec})$ and surface pauses $(4.48 \pm 2.52 \mathrm{sec})$ are relatively short for Little Cormorant. It performed relatively shorter diving times and surface pauses than other diving birds like Redlegged Cormorants Phalacrocorax gaimardi (Frere et al., 2002), Rock Shag Phalacrocorax magellanicus (Quintana, 1999), and Imperial Shag Phalacrocorax atriceps (Croxall et al., 1991). The difference in diving parameters could reflect variation in diving depth which may be correlated with body mass. Among the four species compared in this study the Little Cormorant has the lowest body mass of $444.67 \pm 38.59 \mathrm{~g}(\mathrm{n}=3)$, which comes within the range as referred by Ali \& Ripley (2001). According to Cooper (1986) there exists a relationship between body mass and diving parameters among the family Phalacrocoracidae. As predicted by Cooper dive duration increased with increase of body mass (Fig. 3). But contrary to Cooper's prediction, the diving efficiency of the Little Cormorant is not as low compared to its body mass (Table 2).

The underwater time (66-75\%) observed for Little Cormorant for each dive cycle is almost equivalent to that of Red-legged Cormorant, Rock Shag, and Imperial Shag, but it had shorter dive duration. Little Cormorant is an efficient diver in terms of the proportion of time spent under water per diving cycle as has been described for Redlegged Cormorant (Frere et al. 2002). During low tide and advancing tide the time spent under water increased with decreased diving depth and utilizing the prey availability to the maximum with increased diving efficiency. This shows that in spite of physiological constraints, the bird was not exhausted due to its increased underwater time.

Diving birds may use different foraging tactics to exploit prey in the offshore and inshore waters (Gremillet et al. 1998; Tremblay \& Cherel 2000). In this study mean dive duration and mean recovery time between dives were linked to the height of the tide (diving depth) as described for Red-legged Cormorant (Frere et al. 2002). For longer dives the corresponding rest periods increased and dive/ pause ratio (diving efficiency) decreased as proposed by Stonehouse (1967) at high tide and receding tide. During this condition water depth and volume may increase and prey density fall. Little Cormorants spent more time searching for prey and foraging efficiency decreased at increased diving depth.

Little Cormorants foraging in shallow water during low tide and advancing tide might have fed on fishes shoaling close to the surface as in Japanese Cormorant Phalacrocorax filamentosus (Watanuki et al. 2004). Fishes brought in during high tide may gather during low tide and density increases. These fish groups could be easily detected and foraged with increased efficiency within short dive duration in shallow water. Little Cormorants foraged successfully in shallow water with increased diving efficiency, reducing diving cost and energy as has been noticed in other studies on cormorants (Wanless et al. 1993).

\section{Conclusion}

As in Red-legged Cormorants (Frere et al. 2002; Gandini et al. 2005) the foraging behaviour and diving pattern of Little Cormorant was strongly influenced by many environmental characteristics of the habitat. Our results also suggest that the foraging behaviour of Little Cormorant is influenced by environmental factors such as the height of the tide and diving depth. Low tide and advancing tide seems to be the optimal condition for Little Cormorant to acquire food faster and reduce diving cost. Its preference for shallow water is definitely correlated to its body mass which is reflected in the short dive duration. But the diving efficiency seems to be an indicator of the foraging condition which can be modified according to prey availability. Increase in the prey availability might have enhanced the diving efficiency of Little Cormorant during low tide and advancing tide.

\section{REFERENCES}

Ali, S. (2002). Book of Indian Birds. Oxford University Press, New Delhi, 67pp.

Ali, S. \& S.D. Ripley (2001). Compact Hand Book of Birds of India and Pakisthan. Oxford University Press, New Delhi, 41-42pp.

Altman, J. (1974). Observational study of behaviour sampling methods. Behaviour 49: 227-267.

Ashmole, N.P. (1971). Avian Biology. Academic Press, New York, 224-271pp.

Casaux, R. (2004). Diving patterns in Antarctic Shag. Waterbirds 27(4): 382-387.

Cooper, J. (1986). Diving patterns of Cormorants, Phalacrocoracidae. Ibis 114: 360-366.

Croxall, J.P., Y. Naito, A. Kato, P. Rothery \& D.R. Briggs

Table 2. Mean diving parameters and body mass of cormorants in literature and present study

\begin{tabular}{|l|c|c|c|c|c|}
\hline Species & Body mass (Gm) & $\begin{array}{c}\text { Dive duration } \\
\text { (in sec.) }\end{array}$ & $\begin{array}{c}\text { Pause duration } \\
\text { (in sec.) }\end{array}$ & $\begin{array}{c}\text { Dive / pause } \\
\text { Ratio }\end{array}$ & Authors \\
\hline Red-legged Cormorant & 1300 & 26.80 & 9.20 & 3.25 & Frere et al. (2002) \\
\hline Rock Shag & 1400 & 47.20 & 15.50 & 3.05 & Quintana (1999) \\
\hline Imperial Shag & 2500 & 180 & 60 & 3.00 & Croxall et al. (1999) \\
\hline Little Cormorant & 444 & 10.46 & 4.48 & 2.50 & Present Study \\
\hline
\end{tabular}


(1991). Diving patterns and performance in the Antarctic Blue-eyed Shag Phalacrocorax atriceps. Journal of Zoology 225: 177-199.

Dewar, J.M. (1924). The Bird As A Diver. Witherby, London, $173 \mathrm{pp}$

Frere, E., F. Quintana \& P. Gandini (2002). Diving behaviour of the Red-legged Cormorant, southeastern Patagonia, Argentina. Condor 104: 440-444.

Gandini, P., E. Frere \& F. Quintana (2005). Feeding Performance and foraging area of the Red-legged Cormorant. Waterbirds 28(1): 41-45.

Gremillet, D., G. Argentin, B. Schulte \& B.M. Culik (1998), Flexible foraging techniques in breeding Cormorants Phalacrocorax carbo, and Shags Phalcrocorax aristotelis: benthic or pelagic feeding? Ibis 140:113-119.

Kumar, A., J.P. Sati, P.C. Tak \& J.R.B. Alfred (2005). Hand Book on Indian Wetland Birds and Their Conservation. Published by ZSI \& MoEF, Govt. of India, 64pp.

Lea, S., C. Daley, P. Boddington \& V. Morrison (1996). Diving patterns in shags and cormorants (Phalacrocorax): test of an optimal breathing model. Ibis 138: 391-398.

Lessells, C.M. \& D.W. Stephens (1983). Central- place foraging single prey loaders again. Animal Behaviour 31: 238-2243.
Orians, G.H. \& N.E. Pearson (1979). On the theory of central place foraging, pp. 155-177. In: Horn, D.J., R.D. Mitchell \& D.R. Stairs (eds). Analysis of Ecological Systems. Ohio State University Press, Columbus.

Quintana, F. (1999). Diving behaviour of Rock-Shags at a Patagonian Colony of Argentina. Waterbirds 22: 466-471.

Stonehouse, B. (1967). Feeding behaviour and diving rhythm of some New Zealand shags, Phalacrocoracidae. Ibis 109: 600-605.

Tremblay, Y. \& Y. Cherel (2000). Benthic and pelagic dives: a new foraging behaviour in Rock-hopper Penguins. Marine Ecology Progress Series 204: 257-267.

Wanless, S., M. Corfield, M.P. Harris, S.T. Buckland \& J.A. Morris (1993). Diving behaviour of the Shag Phalacrocorax aristotelis (Aves: Pelecaniformes) in relation to water depth and prey size. Journal of Zoology 231: 11-25.

Watanuki, Y., K. Ishikawa, A. Takahashi \& A. Kato (2004). Foraging behaviour of a generalist marine top predator Japanese Cormorant ( $P$. filamentosus) in years of demersal versus epipelagic prey. Marine Biology 145: 427-434.

Wilson, R.P., K. Hustler, P.G. Ryan, A.E. Burger \& E.C. Noldeke (1992). Diving birds in cold water: Do Archemedes and Boyle determine energetic cost? American Naturalist 140: $179-200$ 